\title{
Ensuring Employment and Employability through Electronics Engineering Education: A Case Study of BPS Women University
}

\author{
Sandeep Dahiya* \\ Department of Electronics and Communication Engineering, Bhagat Phool Singh Mahila Vishwavidyalaya, Khanpur- \\ Kalan, Sonipat, Haryana, India \\ E-mail: sandy_dahiya2001@yahoo.com \\ Vijay Nehra \\ Department of Electronics and Communication Engineering, Bhagat Phool Singh Mahila Vishwavidyalaya, Khanpur- \\ Kalan, Sonipat, Haryana, India \\ E-mail: nehra_vijay@yahoo.com
}

\begin{abstract}
Engineering education plays a pivotal role in the development of technologies, society, nation, economy and employment. It is well evident that in the information age, technology is developing very fast and correspondingly the demand for highly skilled and qualified professionals is also increasing. One of the most critical issues in engineering education is handling placement of young technocrats from an industrial perspective to prepare the required workforce in the $21^{\text {st }}$ century.

The trajectory of development of Electronics Engineering (EE) has intersected every walk of human life. The last decade has also witnessed an assorted increase in Electronics Engineering Education in India. Infact, most of the engineering institutes imparting EE education countrywide focus only on domain knowledge and a mere $25 \%$ of the engineering professionals are actually employable. Along with domain knowledge, there are non-technical skills and competencies which play a significant part in contributing to an individual's effective and successful participation in the workplace.

This article throws light on career opportunities that will go a large way towards ensuring successful career planning and handling placement prospects. The paper addresses the career prospects in a broader domain of electronics engineering and other allied fields. The study will also focus on ongoing activities and initiatives at BPSMV State University in Haryana.
\end{abstract}

Index Terms-Electronics Engineering, Employment, Employability, Scientific computing, Skills.

\section{INTRODUCTION}

Engineering education plays a prominent role in the development of technologies, society, nation, production, economy and employment. It is the art of applying scientific and mathematical principles, and experience to produce a technical product or system to meet out a specific need in the society. India follows $10+2+4$ models of engineering education and most students move directly from one level to another across these 16 years of education [1].

India has seen an unprecedented growth in engineering education over the last two decades with a dramatic increase in student enrolment, number of disciplines and institutions. At present, India has a sound network of technical institution imparting engineering education across the country. Indeed, technical talent is in abundance in India. India has one of the world's largest most qualified pools of technical workforce [2-3].

Looking at the state of Haryana, since the last two decades the horizon of technical education is expanding across the state. Presently, there are about 143 engineering institutes across the states [4] but imparting quality education and ensuring employment and employability of young professional is still a matter of concern. In last decade, the state government also put their emphasis on girl's education. In this direction in August 2006, the State Government of Haryana took cognizance and upgraded the erstwhile Gurukul to the status of a University exclusively for women and christened it as Bhagat Phool Singh Mahila Vishwavidyalaya (BPSMV), which happens to be the first State Women University of North India. BPSMV has the distinction of establishing the centers of excellence like Centre for Indic-Asian Studies (CIAS), Centre for Society University Interface and Research (CSUIR), UGC- Human Resource Development Centre (formerly Academic Staff College), Learning Resource Centre, Staff Training and Research Institute for Teaching of English (STRITE), University Centre for Judicial Services, UGC- NET Coaching Centre etc. [5].

Electronics and Communication Engineering (ECE) Department of the Faculty of Engineering and Technology, BPS Women University aims at educating and training students with sound knowledge and awareness in latest trends in Electronics and Communication Engineering and Information 
Technology. In 2013, Department is segmented from School of Engineering and Science and received University Grant Commission (UGC) assistance for starting M.Tech Information Communication Technology under the "innovative programme" for teaching and research in interdisciplinary and emerging areas. Presently, the department is running UG, PG and research programmes as tabulated in Table 1 with their sanctioned intake.

Table 1. Courses Offered With Sanctioned Intake

\begin{tabular}{|l|l|l|}
\hline S. No. & Course Offered & Sanctioned Intake \\
\hline 1 & B.Tech (ECE) & $60+12$ (LEET) \\
\hline 2 & MBA (Tech) & 60 \\
\hline 3 & M.Tech (ECE) & 18 \\
\hline 4 & M.Tech (ICT) & 20 \\
\hline 5 & Ph. D & As per availability of seats \\
\hline
\end{tabular}

\section{ELECTRONICS ENGINEERING - AN OVERVIEW}

The trajectory of development of Electronics Engineering (EE) and associated fields has intersected every walk of human life. It has a potential impact on virtually all domains of science, technology and society. The communication revolution; penetration of computers in all walks of life; rapid manufacturing of electronic commodities through process control; and great strides based on EE made in diverse fields like defence and space; telecommunication networking; teaching and scientific research; media and entertainment; trade; commerce; health sector; rural development; education and leisure are a few examples of its usefulness. It has been an extremely important ingredient in the rapid development of economy and society, also propelling the pace of globalization [6].

Since the nineteen nineties, much attention has been paid to EE education in state of Haryana because of its potential benefits in innumerable areas. It has made a remarkable progress and there has been manifold increase in professional education in this field. It assures a better employability of young technocrats in govt., semi govt., corporate sector, space sector, multinational companies, PSUs and other organizations through campus selection and off campus during or upon completion of the course [1].

Several leading institutes like, Indian Institute of Technology (IITs); National Institute of Technology (NITs); Indian Institute of Information Technology (IIITs); National Institute of Technical Teachers Training and Research (NITTTR); Central Universities; state Universities; deemed; technical Universities and self funded technical institutions play a major role in imparting EE education countrywide [5-7]. The curriculum of EE programme mainly emphasizes on (a) Network analysis and synthesis, signal and system, electronics device and circuits, linear integrated circuits, instrumentation and control, microprocessor and microcontroller (b) telecommunication i.e. analog and digital communication, wireless communication, microwave communication, electromagnetic theory, antenna and wave propagation, optical communication and networking, satellite communication, digital signal processing/data communication, statistical signal processing, cryptography and network security, image and video processing etc., and (c) Very Large Scale Integration i.e. integrated electronics and circuits/VLSI design tools and technology, analog CMOS integrated circuits, system on chip design, micro electro mechanical system, Hardware description language, embedded system etc along with basic and engineering science and humanities courses [7-9].

\section{A. Career Planning and Mapping}

In today's competitive global world, job hunting is not an easy task. To move ahead in life, one needs to plan career and set goals to make the journey smooth. It is of vital importance to know how to choose and plan one's career, when jobs are available and what kind of preparation is required for getting them. Infact, as an instructor, it has been observed that majority of students reach to the prefinal and final year of their engineering degree without any career planning and awareness about career opportunities. Most of the engineering institutes emphasize on technical competence whereas employers seek for a right combination of skills, academic domain knowledge, attitude, capabilities, competence and multi skilled professionals [10].

Briefly speaking, in the present paper an attempt has been made to provide a brief summary of EE career prospects in India as well as employability skills to ensure employment of young EE professionals. The forthcoming section sheds light on the career prospects in various sectors and organizations for EE professionals.

\section{CAREER PROSPECTS IN EE}

Truly speaking, several career options are open to Electronics Engineers in diverse fields. It enables an individual to pursue a rewarding career with central; state government; corporate sector; public sector undertakings; industry; multinational companies; telecommunication and ICT sector; space sector, teaching and research organizations; defence services; banking and insurance sector; entrepreneur; engineering and management consultancy; Indian engineering services and so on. The forthcoming sub sections shed light on the career prospects in various diverse sectors and organizations for EE professionals.

\section{A. Public Sector Opportunities}

Electronics engineering professionals can pursue a rewarding career in public sector undertakings (PSUs). At present, there are about 277 central PSUs in India which provide a career for both technical and non-technical personnel. A lot of PSUs under the aegis of government of India regularly provide employment opportunities in EE domains. EE professionals can apply to these undertakings according to their required job profile and area of interest. The central PSUs employ a large 
workforce in various areas of $\mathrm{EE}$ and the successful operation of these enterprises very much depends on the skills and capabilities of the workforce.

The various PSUs offering employment to EE professionals are:

- $\quad$ Bharat Heavy Electricals Limited (BHEL);

- National Thermal Power Corporation (NTPC);

- Bharat Electronics Limited (BEL);

- Central Electronics Limited (CEL);

- Indian Telephone Industries Limited (ITI);

- Electronics Corporation of India Limited (ECIL);

- Hindustan Aeronautics Limited (HAL);

- Telecommunication Consultants of India Limited (TCIL);

- Indian Oil corporation ltd (IOCL);

- Gas Authority of India Limited (GAIL);

- $\quad$ Power Grid Corporation of India Ltd (PGCIL);

- Air India Limited;

- Airports Authority of India;

- Bharatiya Nabhikiya Vidyut Nigam Limited (BHAVINI);

- Heavy Engineering Corporation Limited (HECL);

- HMT Limited;

- Instrumentation Limited, Kota;

- National Hydroelectric Power Corporation Limited (NHPC);

- Nuclear Power Corporation of India Limited (NPCIL);

- $\quad$ Oil and Natural Gas Corporation Limited (ONGC);

- $\quad$ Oil India Limited (OIL);

- $\quad$ Pawan Hans Helicopters Limited (PHHL);

- RailTel Corporation of India Limited;

- Semi-Conductor Laboratory formerly Semiconductor Complex Limited (SCL);

- $\quad$ Steel Authority of India Limited (SAIL).

- Delhi Metro Rail Corporation (DMRC)

Besides the above stated PSUs, many other PSUs also offer employment opportunities to EE professionals as trainee engineers; graduate engineer; electronic engineers; management trainee etc.

All these organizations have their own recruiting procedures and many of them recruit directly from prestigious engineering colleges. These PSUs also recruit EE professionals through off-campus by giving wide publicity in employment news and leading news papers on the basis of Graduate Aptitude Test in Engineering (GATE) score. Some of these PSUs conduct competitive type technical written, group discussion and interview rounds. In nutshell, PSUs in India offer a stable and secure employment and most of them hold all-India based recruitment examination [11].

\section{B. Telecom Sector}

Electronics is an emerging area having a potential impact on virtually all domains of science, technology and society. The development of telecommunications has now become a basic need of the modern society and a measure of its economic, social and cultural developments. In fact, the telecommunication sector has shown massive upsurge in the recent years in all respects of industrial growth. It is one of the fast growing fields of the world. The telecommunication sector offers ample opportunities at all levels and future prospects for EE professionals are also bright in this sector. India is the fastest growing and the second largest market in the world. The various telecom companies need skilled engineers in various fields like administration, networking, customer support, sales marketing IT, finance and related. Majority of the job opportunities are in the area of solutioning, product management, project's roll-out and management, customer support, manufacturing and remote infrastructure management. The EE professionals find regular job opening in telecom sector for various openings such as switch engineer, radio frequency (RF) engineer, network operations centre (NOC) engineer, operation support system (OSS)/base transceiver station (BTS)/business support system (BSS) engineers etc.

Telecommunication sector is the life line of ICT industries and India is the fourth largest market in Asia. At present, the country's telecom industry has achieved a growth rate of $14 \%$. Its contribution to GDP of India is of $2.1 \%$. Today the Telecom industry offers services such as fixed landlines, wireless local loop (WLL), global system for mobile communication (GSM), code division multiple access (CDMA) and internet protocol (IP) services to customers. The growth of mobile sector in India has witnessed increased opportunities in the telecom market with the advent of wireless-in-local-loop technology. Further, mobile and wireless technology has become a fire wave of the future to benefit every aspect of our life including business, personal, education, medical, entertainment as well as global communication.

As a result of Indian telecom industry's rapid evolution, the opportunities for technocrats are enormous. The professionals can also explore career in Mahanagar Telephone Nigam Limited (MTNL) and Bharat Sanchar Nigam Limited (BSNL), the major public-sector players of telecom sector. Moreover, there are number of MNC/industry/private players which offer employment opportunities to EE professionals in telecommunication sector. PSUs such as Bharat Sanchar Nigam Limited (BSNL)/Mahanagar Telephone Nigam Limited (MTNL) offer the post of Junior Telecom Officers (JTOs) and Technical Telecom Assistants (TTAs) in telecom sector.

Apart from above, the EE professionals having an engineering degree with specialization in mobile computing, wireless, telecommunication or any other stream related specifically with networking can also start career as mobile phone system engineer, android, blackberry, iPhone, windows mobile applications developer, mobile applications testing specialist, IPAD developer, game developer, mobile architect/mobile software platform architect, mobile technicians, mobile plant equipment mechanic, telecommunications tower installation and maintenance engineer, mobile security expert, mobile phone verification manager, mobile 
architect, customer care officer, marketing manager, technical support engineer, KPI (Key Performance Indicator) engineer etc.

With the continuing fast growth of telecom services, large service providers such as Bharti Airtel, Vodafone, Tata Telecom and Reliance also recruit Electronic Engineers on large scale. There are a huge number of multinational corporations dealing in manufacturing, sales and services of electronics consumer goods and appliances at national and international level. Organizations associated with design, development, consultancies, and R\&D also need such professionals. One can also pursue career in software sector as telecom system solutions engineers, telecom software engineer, system programmer, information system designer, application programmer, system analyst, internet service provider, practical design engineer, and dot com carrier in various organizations. Moreover, in telecommunication sector one can work as image processor, video engineer, network engineer, antenna \& RF design engineer, communication engineer etc [12-14].

In nutshell, the telecommunication sector holds unprecedented potential and has enormous employment opportunities for EE professionals.

\section{Networking Sector}

EE graduates having sound understanding of computer hardware, having interest in computer technology and eager to work with computers and troubleshooting give a cutting edge to the aspirant and have ample opportunities in networking. Computer networking refers to the process of connecting two or more computers using hardware and software tools thereby supporting data communication among the devices. Computer networking has pervaded almost all the spheres and sectors (govt, semi govt, public or private) such as health care, education, commerce, telecommunication and many others. Networking encompasses providing configuration, installation operation, monitoring network logs, diagnosing and troubleshooting problems, adding new server and providing assistance, support to end users with respect to evaluating vendor's products, system upgrades and numerous such activities. The design, installation, infrastructure and management of day to day activities are the prime responsibilities of networking workforce.

In this information age, with the internet and telecom based applications, the demand of network specialists is increasing and expected to continue for next couple of years. Network professionals need to have a good command over both software and hardware as they are not isolated from any function and need to keep a tab on everything. Global certification courses offered by leading IT companies like Microsoft, CISCO and Sun Microsystems, besides providing hands on experience are an added advantage for pursuing a rewarding career in networking field. Some of the popular international certification available for LAN/WAN administration is MCSE, UNIX, Admin, LINUX Admin, CNE etc., while for WAN administration one needs relevant vendor's certifications like Cisco Certified Network Associate
(CCNA), Cisco Certified Network Professional (CCNP), Cisco Certified Design Associate (CCDA), Microsoft Certified Professional (MCP), Microsoft Certified System Administrator (MCSA), Microsoft Certified System Engineer (MCSE), Microsoft Certified Solution Developers (MCSD), Certified Information System Security Professional (CISSP), Cisco Certified Internetwork Engineers (CCIE), Cisco Certified Security Professional (CCSP), Certified Information Security Manager (CISM), Security Expertise in Management (CISSP-ISSMP), Security Expertise in Architecture (CISSP-ISSMP) etc.

The various job titles in this domain for professionals include: System administrator, network administrator, network programmers and analyst, network managers, network engineer etc [15].

\section{C.I Information Security Professionals}

In recent times, threats to network security from hackers and other cyber crimes are on the rise. EE professionals can also explore opportunities in security sector. The use of ATM cards, credit cards, debit cards, ebanking, e-ticketing for railway and flight reservation, eshopping, e-tax returns, e-business, mobile phones; social networking websites have become routine chores in our lives. The major organizations such as banks, financial institutions, travel and leisure industry, e-commerce, government, military, police, business process outsourcing (BPO), telecommunication, IT enabled services, software developers, entertainment, education, manufacturing will be prospective employer for information security professionals.

ICT revolution has thrown up a major challenge-the information security. All of us are aware of the risks like phishing, pharming, botnets, rootkits, malware etc in the use of information technology. The cyber-crimes have given rise to a new breed of specialists- Information Security professionals with a slew of career opportunities.

Job opportunities for information security professionals are enormous. Today, the most respected and popular security certificates for information security professionals are Certified Information Systems Security Professional (CISSP), Certified Information Security Manager (CISM), Certified Information Systems Auditor (CISA) and the Global Information Assurance Certification (GIAC) certificates provide the prospects for employment in this sector. These professionals also have opportunities as trainer in cyber law and security centre, cyber crime expert in police department and intelligence bureau, legal expert in law firms. Cyber security professionals are also required in forensic fields. The expansion of egovernances at the grass root levels across the country may further escalate the need of such professionals in various government and non government organizations [16].

The information security professionals can start their flourishing career as:

- Chief Information Security Officer

- Network Security Specialist 
- Digital Forensic \& Incident Response Analyst

- Information Security Auditor

- Security Architect

- Vulnerability Analyst

- Penetration Tester/ Ethical Hacker

- Information Security Systems \& Software Development Specialist

- Information Security Risk Analyst

- Cyber expert and consultant.

\section{Hardware and Software Sector}

As the technology sector continues to grow day by day, there is demand for EE professionals who have a blend of hardware and software knowledge and skills.

Further, the ICT sector offers a variety of career prospects in software, hardware, multimedia and networking, communication design and management. The two main sectors offering opportunities in this field are (1) hardware (2) software. Hardware, a segment of ICT sector and electronics industry deals with the designing, manufacturing, research and development, maintenance of electronics and telecommunication devices, computers and assembling of the manufactured components range from circuit boards and microprocessors to routers. With the advancement of technology and development of computing devices, communication system, consumer electronics, cellular growth, there is a need of hardware engineer in a wide range of services.

\section{D.I Software Sector}

Since the last decade, software sector as a segment of the ICT industry is also attracting several young electronic engineers. All hardware electronic equipments need software backing for better performance and more features availability. The EE professional can better judge what features can be introduced newly in the existing series and how they are programmed to perform useful tasks. Moreover, EE professionals may develop, design and test software; design, construct and maintain computer programs for companies; set up network such as intranet for companies; make or install new software or upgrade computer systems; work in application design to meet the needs.

Leading ICT and software organizations in India like TCS, Microsoft Corporation, Accenture, IBM, Hewitt technologies, Patni, C-DOT, Polaris, Appin Knowledge Solutions, Hughes Software, Toshiba, Oracle, Havells India Limited, RedHat, Novell, Encore Software Limited, Wipro, Satyam Infosys, Dell Computers, Nokia Siemens, ALCTEL, Jupiter Systems Software, SONY, Samsung, Videocon, LG, IDEA, Samtel, NIIT, Beetal, Tech Mahindra, Bharti telecom and many more companies recruit the professionals through campus/off campus for expanding their horizon. In nutshell, ICT sector holds unprecedented potential and has enormous employment opportunities.

\section{E. Opportunities in VLSI and Embedded Design}

Global demand for consumer electronics and semiconductor is rapidly increasing. This growing demand provides wide career options in the field of VLSI and embedded design. India having talent in software development is now taking charge in VLSI design and presently, there are about 130 companies working on chip design. According to a report by Indian Semiconductor Association (ISA), semiconductor industry is expected to provide 3.5 million jobs by 2015. The chip design companies offer exciting career opportunities for young engineers, those looking to develop cutting edge technologies. Entry-level qualification is B.E./B.Tech in electronics and other associated fields. Master's degree in the relevant subject is an added advantage.

\section{E.I Embedded Systems}

The field of embedded systems is growing rapidly as a result of innovative application in communication, internet appliance, consumer electronics, security and surveillance, defence and avionics, industrial; telecom, automotive, computing, medical electronics, particularly portable monitoring devices and process control finding applications in diverse fields of engineering are growth drivers for this sector. The players in this sector include system integrators, IC design houses, electronic design automation vendors, board design houses, test houses, software tool providers, and embedded software and application software providers. There is a huge need for talents in the area of embedded system design, development and production.

Embedded system is a team work involving three different sets of experts: hardware engineers, software engineers and application domain experts. Hardware engineers are responsible for hardware platform and module prototyping, debugging and testing, ensure compliance with standard and product specification. Software engineers work as embedded system programmer responsible for analysis and optimization of embedded software for targeted real time operating system (RTOS). An embedded system application programmer designs and develops applications such as personal digital assistants (PDA), digital audio player, portable medical equipments, cellular phones, all of which require integration of hardware and embedded software.

Truly speaking, there is a huge demand for professionals with knowledge and skills in embedded system design, digital application specific integrated circuit (ASIC) design, VLSI design and such more technologies. So, a course in embedded systems design after graduation can ensure a potential for growth in the future.

Looking at skill set required in this domain, it is observed that there is a need for training and real life design exposure before they can become productive. In the software line of this domain basic knowledge of $\mathrm{C}$, assembly language programming and special networking protocols along with fundamentals is a must. On the other side, expertise in fundamentals of electronics, digital and analog design techniques, microcontroller and microprocessor, PCB design, real time operating system may be helpful to explore career opportunities in this 
field.

Professionals with knowledge of embedded system design are very rare despite the fact that this is one of the growing sectors of electronics. Global leading companies such as Cisco, Texas Instruments, ST Microelectronics, Cadence Design Systems, Juniper, LG, Honeywell, GE, Bosch, Delphi, Huawei, Visteon, Continental and many more have set up their embedded development centres in India. Besides, design service companies of India like Wipro, HCL, Infosys, Mintree, L\&T, TCS, Tata Elxsi, KPIT Cummins and other too are doing embedded software and hardware product development in India for a global account. Moreover, various private and publicsector organizations accommodate final-year and prefinal-year students in their live projects with respect to design and documentation, development of prototype modules, coding and unit testing [17-18].

\section{E.II VLSI design}

There are two main aspects in VLSI design, namely front end and back end. Front end design includes digital design using hardware description language and design verification using simulation and formal verification techniques, synthesis of digital design to gates and design for testability. The VLSI design engineer must have exposure to fundamental concepts as well as familiarity with tools and design flow. Whereas back end design consists of CMOS library design and characterization, physical design, design for manufacturability, packaging, test generation and fault simulation.

Candidates willing to join semiconductor industry, VLSI design and embedded would be expected to have technical skills in the areas of embedded system, microcontrollers, VLSI design and simulation tools, digital signal processing etc. The candidate willing to enter in VLSI domain is expected to know the physics of semiconductor devices, linear systems, probability and random variables, engineering mathematics, circuit analysis and engineering electromagnetic. Besides these, one should have sound verilog and VHDL skills, familiarity with front end design cycles, synthesis and simulation tool knowledge, sound digital design fundamentals and knowledge of microprocessors.

Companies are looking for professionals having some experience in digital design, physical design, mixed signal IC design, VHDL, Verilog, Microcontroller etc. Therefore, short-term training programs related to the design, development and deployment of advanced IT based solutions offered by National Institute of Electronics and Information Technology (NIELIT), Centre for Development of Advanced Computing (CDAC), IITs and other organizations are always an additional advantage for EE professionals.

The EE professionals having sound understanding of fundamental concepts may start career as a design engineer, chip architect, application engineer, CAD engineer, product engineer, test engineer, circuit designer etc in many international and national players.

Leading VLSI design Companies such as Cisco, HCL, Texas Instruments, IBM, Intel, Philips, Alliance
Semiconductors, CMOS Chips, Mentor Graphics, Silicon Automation Systems, Spike Technologies, Sun Microsystems, DCM Data Systems, CG-Corel, VLSI India, Bit Mapper, ICON Design Automation, Lucent Technologies, Rhydo Technologies, Embedded Wireless Limited, ATI Research Silicon Valley Limited, STMicroelectronics, Cadence, Motorola, Cypress Semiconductor, Delsoft, EDA India, Horizon Semiconductors, Microchip Technology, Sanyo LSI Technology, Semiconductor Complex Limited, Sequence Design and others also recruit professionals as hardware and software engineers through campus/off campus selection [19].

In nutshell, there are enormous employment opportunities in VLSI and embedded sector for EE professionals.

\section{F. Defence Opportunities}

EE professionals can pursue a rewarding career in defence services in various wings of Indian Air Force, Navy, Army, Coast Guard as Short Service Commission (SSC) and permanent commission (PC). The candidates joining as PC would continue the defence services till superannuation, whereas the tenure of SSC will be for a period of 10 years extendable by a further period of 04 years subject to the service requirement and performance/willingness of the candidates. An electronics engineer can join Indian Air Force in flying branch as fighter/helicopters/transport pilot through combined defence service examination (CDSE)/national cadet corps (NCC) special entry/flying pilot scheme or technical branch via direct entry scheme (DES) as aeronautical Engineering (electronics) and University Entry Scheme (UES) after rigorous training regimen at one of the air force training establishments. Besides Indian Air Force, one can enter in Indian Army through UES or Technical Graduate Course (TGC). Apart from above, one can opt the executive/technical/ education branch of Indian Navy.

The entry in Indian Air Force is made through Air Force Common Entrance Test (AFCAT). It is two hour duration consisting of multiple choice questions on verbal ability, numerical ability, reasoning, general awareness and military aptitude. Candidates short listed on the basis of AFCAT will be called for further testing. The testing consists of three stages. The stages I test consist of intelligence test along with other tests conducted on the same day. It is a screening test and only those who qualify the same undergo subsequent testing. The stage II consists of psychological test, group test and interview which are conducted on the subsequent day.

The male EE professional studying in the final year of their programme and having a minimum of $60 \%$ aggregate marks may explore opportunities in SSC of Indian Navy in executive (general services, pilot, and observer) and technical branch (electrical) under University Entry Scheme. The eligible candidates applying for entry will have to appear before a Naval Campus Selection Team for interview. The candidates qualifying the campus interview are shortlisted for SSB interview on the basis of preference for entry. The stage I 
test consists of Officer Intelligence Rating (ORI) Test, picture perception, and discussion test which is conducted on the first day. It is a screening test and only those who qualify undergo subsequent testing. The stage II comprises of psychological testing, group task, group discussion and personnel interview.

The Indian men or women having EE degree with $60 \%$ aggregate marks may explore the opportunity to become an officer as Assistant Commandant, Deputy Commandant, Commandant (JG), Commandant, DIG, IG or in various branches as a group ' $\mathrm{A}$ ' Gazetted Officer in Indian Coast Guard, an Armed Force of Union. The professionals having higher percentage will be shortlisted for $1^{\text {st }}$ stage. The shortlisted candidates will be called for preliminary selection consisting of mental ability test, picture perception and discussion test. The qualified candidates of preliminary test are called for final selection consisting of psychologist test, group testing and interview.

One who wants to join the Indian defence force should meet the physical standards and fulfil the general eligibility criterion like vision, height, weight, age, marital status, qualification, nationality and must be physically/medically fit as per laid down standards. Proficiency in sports, swimming and extra-curricular activities is an added advantage. As compared to other professions in the civilian's world, the service in Indian defence workforce offers attractive pay packages and perks, dignity, status, canteen facilities, group insurance cover, soft loans for house and vehicle, free medical benefits for self and family and adventurous activities of their own choice. Adventurous activities like mountaineering, sailing, yachting, water sports, polo, aero-modelling, golf, gliding, sailing, wind surfing, astronomy, photography and many other sports games are easily assessable. The entry in Indian defence force empowers an individual with core values like sense of responsibility, duty and discipline, analytical thinking, planning skills, administrative and organizational abilities, essentially the traits that can promote self control to achieve success in life [20-21].

\section{G. Teaching and Research Prospects}

The EE professionals having sound academic background, great communication skills, interest in teaching and excellent domain knowledge can join the teaching profession as faculty members across the globe. One can work as technical assistant, senior technical assistant, technical officer, assistant professor, associate professor, professor after B.E./B.Tech/master's/doctoral degree in various state, central, deemed, technical Universities, NITs, IITs, IIITs, NITTTRs, National Institute of Electronics and Information Technology (NIELIT, formerly DOEAC), Indian Institute of Space Science and Technology (IIST) and other govt and self financing technical institutes of repute. The key responsibility of profession includes teaching, research, training, laboratory development, curriculum planning, content development, educational administration, planning, management and execution.
Principally, majority of students intend to be employed after acquiring the engineering graduate degree. But with a B.E/B.Tech degree, there are limited opportunities to pursue a career in teaching and research. However, candidates having UG degree with valid GATE score may get opportunities in teaching and research and various research and development institutions as:

- Technical Assistant

- Senior Technical Assistant

- Technical Officer

- Research Assistants/Associates etc.

Candidates having PG/PhD degree with good academic record may get opportunities at initial level in teaching or as research fellow in various $R \& D$ projects. At present, most of the academic institutes offer regular/temporary/contractual employment to such professionals as Associate Professor, Assistant Professor, Research Associate etc. The professionals may also start career as faculty at Universities, pursue independent research, publish papers, guide research students, teach classes, member of academic committees, referee papers for publication etc.

Besides teaching and research prospects, scientific research and development also play a vital role to offer unprecedented potential for employment to $\mathrm{EE}$ professionals [22-23].

\section{H. Scientific Research and Development Opportunities}

Scientific research and development also plays an important role in national technological developments. Besides teaching, research holds tremendous scope and bright future prospects in electronics and other related interdisciplinary areas. Independent and collaborative research in various domains of $\mathrm{EE}$ such as electronics systems, electron tubes, semiconductors, nanotechnology, plasma electronics, communication and broad band technique, industrial electronics, information security, rural application, emerging area of ICT, human computer interface and other areas too can be pursued by the researchers [24].

Although there are limited options for research in India but the professionals having PG/doctoral/post doctoral qualification can also pursue career as research assistant, research associate, scientific officer, scientists $B, C, D, E$, $\mathrm{F}$, and find challenging avenues in various $\mathrm{R} \& \mathrm{D}$ labs. One can pursue career in various $R \& D$ laboratories base of Defence Research and Development Organization (DRDO) via direct entry through Scientist Entry Test/ Registration of Students with Scholastic Aptitude/Campus Selection process/ Lateral Entry Scheme. The DRDO has a network of 50 laboratories in various divisions such as aeronautics, armaments, combat vehicles and engineering, human resource development, life sciences, materials and naval etc.

Apart from DRDO, one can get opportunities as Scientific Officers in the Department of Atomic Energy research \& development sector under scheme of one year orientation course for engineering graduates (OCES)/two- 
year DAE graduate fellowship scheme, Dr. K.S. Krishnan Research Associateship (KSKRA), Direct recruitment through open advertisements for engineering graduates. Successful trainees under OCES will be posted as scientific officers in various DAE units [25].

EE professionals can also join the various organization of "ISRO-Department of Space" as scientists at different levels through various schemes such as:

1. Centralised recruitment,

2. Live registration for Ph.D professionals,

3. Manual submission of applications in different centres/ units of departments of space from time to time.

Besides DRDO, ISRO and DAE, one can also enter as a scientist at different levels in various $R \& D$ organizations of CSIR. At present, CSIR has 39 R\&D laboratories in India to embrace the science and technology professionals in diverse fields. It also provides:

- Senior Research Associate ship (SRA ship),

- Emeritus Scientist (ES),

- Visiting Associateship (VA).

One can also apply for teaching-cum-research fellowship in various technological Universities in India. Each teaching cum research fellow will be allowed to enrol for a full time $\mathrm{PhD}$ programme and will take teaching activities at UG/PG level. One can also get scholarship from various NITs, IITs, IIITs, NITTTRs, IISER and Indian Universities to pursue research work.

In summary, teaching and research offer ample opportunities for EE professionals.

\section{Indian Engineering Services Examination}

The EE professionals having sound domain knowledge can also appear for Indian Engineering Service Examination conducted by Union Public Service Commission (UPSC) [26]. The engineering service examination consists of two sections: section I consist only of objective type of questions and section II of conventional papers. The scheme of examination for Engineering Service Examination comprises of two papers. The paper $1^{\text {st }}$ consists of courses viz Materials and Components, Physical Electronics, Electron Devices and ICs, Signal and Systems, Network Theory, Electromagnetic theory, Electronic Measurement and Instrumentation and paper $2^{\text {nd }}$ consists of Analog Electronic Circuits, Digital Electronic circuits, Control System, Communication Systems, Microwave Engineering, Computer Engineering etc. The examination consists of a written examination of 1000 marks followed by an interview for personality test of 200 marks. The recruitment of qualified Electronics and Telecommunication Engineering professionals are made under the following categories: [27]

- Indian Railway Service of Signal Engineers
- Indian Railway Store Service

- Indian Ordnance Factories Service

- Indian Naval Armament Service

- Assistant Executive Engineer (in Ministry of Defence)

- Engineer in Wireless Planning and Coordination Wing/Monitoring Organization

- Assistant Naval Store Officer (in Indian Navy)

- Survey of India Service etc.

\section{J. Manufacturing Industries}

EE professionals can also start a rewarding career into a variety of private sectors such as automobile, textile, manufacturing industries, robotics, aerospace, automotive industry, consumer electronics, industrial electronics, industrial automation, medical electronics, defence and space, lighting and home automation industries, electrical industries and biomedical equipments manufacturing unit etc. Infact, with increasing automation and sophistication of technologies in the manufacturing and process industries there are challenging opportunities for electronics-oriented graduates in industry.

\section{K. Robotics Sector}

Electronics professionals may also find opportunities in the design section of a robot manufacturing firm. The aspirants may work on electronic design and embedded programme for robotics assembly like actuators, sensors and interface circuitries and develop innovative GUI interface and control mechanism for robots, troubleshooting and maintenance [28].

\section{Power Sector}

Electronics professionals may also plunge in power sector. The work opportunities in the power sector include creation, expansion and enlarging of existing units, upgradation of the existing capacity through modernization of equipment and introduction of new technologies and instrumentation. Primarily, it is a technical field and so domain expertise and process knowledge are very important. The professionals working in this sector come across the basics of analog circuits, electronic devices, control system, power system, magnetic, electrical machine and numerical solution [29].

\section{SMT Sector}

EE professionals can also explore opportunities in surface mount technology (SMT). The SMT players are characterised into SMT production equipment suppliers and SMT equipment users for manufacturing. Juki, Panasonic, American Tec, Tyco and CDIL are some of the prominent names in the SMT field. As an SMT engineer, one can work either at the manufacturing plant handling the process line or in the service sector dealing with maintenance and troubleshooting of SMT machines. Professionals willing to enter in this field should know the basics of electronic circuit design and production technology, the basic theory and application of SMT operation, process flow of SMT, soldering techniques and solder paste, basic principles used for SMT, software and 
hardware related to the SMT process, maintenance and quality control procedures and protocols in the SMT process and also storage, shipping and handling of SMT products [30].

\section{N. Consultancy and Own Work}

Apart from the above stated opportunities, willing EE professionals can also start their own business and therefore entrepreneurial openings are also available for such professionals. Entrepreneurship development can be nurtured, and fairly a good percentage of students can become successful entrepreneurs. EE technocrats also have ample opportunities to work in the service sector as an entrepreneur. Moreover, the EE professionals can provide expert guidance, scientific and informational services for outsourcing knowledge to diverse business sectors and industries in order to enhance their technical productivity and to successfully manage technological processes. Such professionals may also provide consultancy to give professional advice and technical support to clients of industries for concept studies and new developments. One can work in the following area: (1) Manufacturing, repairing, assembling of electronic devices components, consumer electronics, household appliances, industrial equipments, health care system, home appliances, security system, entertainment industry, animation, computer, hardware and software support for academic institution etc. (2) InfoTech: Network programming, installation management, internet applications, e-commerce, web security, IT enabled service, data digitations, IT marketing, technical writing. (3) Telecom: marketing/sales/franchise executive etc.

\section{O. Abroad Opportunities}

Numerous opportunities exist in the overseas countries for the deserving EE professionals. One can avail various fellowships to pursue PG/Ph.D and post doctorate studies to go abroad. Moreover, the EE specialists from India can also get opportunities aboard in multinational companies, teaching and research, corporations, federal, govt and nonprofit charity organizations and others too. Many organizations are hiring Indian professionals for working in countries like USA, UK, UAE, Saudi Arabia, Qatar and many other countries.

\section{P. Space Sector}

Space sector offers the most exciting career option for engineering professionals and scientists in various departments of astronomical and space science in India and abroad. Space technology affects almost every part of human lives i.e. weather forecasting, satellite TV, global communications or satellite navigation. To build up a successful career in space science one should have computational, mathematical and logical skills needed to analyze and solve the complex problems and must develop his personality.

To sum up, EE professional have exciting opportunities in diverse sectors, flexible working environment and attractive packages. The pay package offered to EE professional depends on candidate's educational qualifications, skill set, work experience and expertise, critical aspects of jobs, hierarchy and varies with educational background.

Keeping in view the discussion, it is obvious that there are ample opportunities in diverse sectors for EE professionals. One can explore career opportunities in diversified sectors as discussed here.

\section{SIGNIFICANCE OF GATE}

The Gratitude Aptitude Test in Engineering (GATE) is vital for engineering professionals in their career planning and mapping. It focuses on core subjects of EE discipline such as engineering mathematics, network graph, electronic devices, analog circuits, digital circuits, signal \& system, control system, communication and electromagnetic etc. B.E./B.Tech degree holders in EE and those who are in final year of such programmes, or who have obtained equivalent qualification through AMIE, or those who have completed Sec A of the same can apply for GATE.

The countrywide admission to PG programme is made on the basis of the GATE, an all-India examination After qualifying GATE, one has to apply for admission in individual institution such as IISc, IITs or NITs or other institutions of repute at their own level. The students admitted on the basis of GATE in PG or doctoral programme in engineering gets financial assistance supported by MHRD or other government agencies. Moreover, several PSUs such as ONGC, NTPC, ISRO, BHEL, BARC, DRDO, Power Grid, IOCL and many other organizations recruit EE graduates only through GATE criteria. Besides, GATE qualified candidates also become eligible for the award of junior research fellowship in CSIR laboratories [31].

\section{MANAGEMENT PROGRAMME OPPORTUNITIES}

Learning management skills is undoubtedly very useful for EE professionals. Apart from the above opportunities, young $\mathrm{EE}$ professionals also prefer management programme for successful career in various organizations. One can pursue PG in management from various institutions across the country such as Indian Institute of Management (IIMs); Indian School of Business; Xavier Labour Relations Institute; Faculty of Management Studies, Delhi; Tata Institute of Social Science, Mumbai; Management Development Institute, Gurgaon; Jamnalal Bajaj Institute of Management, Mumbai; ICAFI Business School, Hyderabad; Symbiosis Institute of Management Studies, Pune; IMT, Ghaziabad; National Institute of Industrial Engineering (NITIE), Mumbai; Amity Business School, Noida; FORE School of Management, Delhi; International Management Institute Delhi; Nirma Institute of Management, Ahmedabad; central/state/technological and deemed Universities and many more. These institutes/universities offer various specializations such as marketing, human resources, finance, agri-business, telecom and mass media, 
information technology management, operations, hospital management, foreign trade and software enterprise, knowledge and technology management, supply chain management on either regular basis for two years or part time/distance based education for three years.

One possessing strong leadership qualities, the ability to take the responsibility, result oriented approach, entrepreneurship, excellent communication and interpersonal skills, problem solving skills, being a good judge of competencies and personalities certainly helps in career planning in management. With adequate qualification in management, one may have a career that offers good working conditions, excellent remuneration and good career growth opportunities at national and global level.

The country wide admissions to professional courses are made based on eligibility test and there are a variety of such tests. There are several management admission tests such as: (1) Common Admission Test (CAT) conducted by the IIMs; (2) Xavier Admission Test (XAT) conducted by Xavier Labour Relations Institute, Jamshedpur; (3) Management Aptitude Test (MAT) conducted by all India Management Associations, New Delhi; (4) ATMA-Association of Indian Management Schools (AIMS) Test for Management Admissions; (5) JMET admission to IITs and IISc; and (6) Graduate Management Admission Test (GMAT) followed by group discussion and personnel interview. GMAT score is globally recognized qualification for admission to MBA programmes accepted in USA and the world over as part of the application process for many MBA programmes. The CAT and XAT are the eligibility tests for admission to selected few primer business schools (BSchool) in India. MAT has been utilized by several lakhs of students to gain admission for MBA. In fact, hundreds of B-Schools have been utilizing the MAT examination as screening test to admit students to MBA programme. Most of these tests are multiple choice examinations. CAT examination focuses on verbal ability and reading comprehension (2) data interpretation selection and (3) mathematical ability. MAT has five sections-language comprehension, mathematical skills, data analysis and sufficiency, intelligence and critical reasoning and Indian and global environment.

There are a number of placement and recruitment agencies which offer good opportunities to management professionals. As per the area of specialization, management professionals are recruited in govt, semi govt, PSUs, NGOs, social organizations, insurance banking, multinational companies, teaching and research, career consultancy and other areas too. If management professionals are academically inclined, there are opportunities to teach management related courses at universities, colleges and management institutes [32].

\section{BRIDGING DomaIn KNOWLEDGE GAP THROUGH PROFESSIONAL TRAINING}

Truly speaking, it is well realized by most of the industry veterans that there is a need to bridge the gap between the quality of knowledge imparted by engineering institutions and industry requirements. Curriculum development is a slow process as compared with the industry pace. A suitable training institute may be a good alternative to bridge the domain knowledge. Keeping in view the same, EE technocrats can also go for advance diploma/certificate course/short term training programme of one week to six months to upgrade the technical skills and hands on experience in various specialized fields like VLSI design, microcontroller and embedded system design/wireless and mobile computing/information system and cyber security/EDA tool/digital signal processing/hardware and networking, industrial automation system etc. These courses are unique programmes aimed at imparting dedicated training in thrust areas of EE and related fields. These short term courses are beneficial for continuous up gradation of knowledge and skills that become a necessity due to rapid advancements in technologies.

Therefore, short-term training programs involved in the design, development and deployment of advanced IT based solutions offered by National Institute of Electronics and Information Technology (NIELIT), Centre for Development of Advanced Computing (CDAC), IITs, National Small Industry Corporation Technical Service Centre (NSIC) and other organizations are always an additional advantage for EE professionals. The department of Electronics Science, University of Pune also offers six month certificate course in advance computing and embedded system design. Moreover, various centre for Development of Advanced Computing (CDAC), across country also offers short term courses in networking and system security, and biomedical equipment technology and maintenance [23].

However, there is a need for a skilled workforce in each respective domain. As per a report by NASSCOM, a mere $25 \%$ of engineering professionals are actually employable. There are non technical skills and competencies which play a significant part in contributing to an individual's effective and successful participation in the workplace. Therefore, the forthcoming section focuses light on employability skills and training need of EE professionals.

\section{ENSURING EMPLOYABILITY SKILLS}

Studies conducted by the National Association of Software and Services Companies (NASSCOM) and Federation of Indian Chambers of Commerce and Industry (FICCI) reveal that $75 \%$ of engineering graduates are unemployable. This was further confirmed in an industry survey conducted by Indian Electrical and Electronics Manufacturers Association (IEEMA) during 2008 in western region [33-34]. A lot of factors such as geographically diverse talent pool, lack of career prospects, lack of personnel attributes and skills in academic curriculum lead to an employability gap. A limited availability of skilled workforce-ready to be deployed trained, technically competent and equipped with skills needed by the industry is a major concern and 
needs an urgent redressed. The forthcoming section sheds light on employment and employability skills essential for young technocrats.

\section{A. Meaning of Employment and Employability}

Employability skills refer to specific skills essential for employment. It refers to a person's capability of gaining initial employment, maintaining employment and a switch over of the jobs comfortably. Employability is convergence of several skills, abilities, knowledge, competencies and capabilities that enable individuals to get employment and a successful professional career. Employability skills are all about the ability of individuals to exhibit their skills to the prospective employers and the ability to execute the tasks thereby achieving organizational goals and objectives. It not only depends on whether one is able to fulfil the requirements of specific jobs, but also on how one stands relative to others within a hierarchy of job seekers. The needs of employability skills differ from country to country and from sector to sector and from time to time. However, certain qualities such as communication skills, interpersonal skills, integrity, right attitude, problem solving, decision making and team building skills can be taken as a few common skills of employability.

People often confuse between unemployability and unemployment. Unemployability arises when individuals have educational eligibility but lack in capability and suitability to execute job related activities despite there being the availability of employment opportunities. Unemployment is a state where individuals have educational eligibility, capability and suitability but scarcity of employment opportunities. The current situation in India is more of unemployability rather than unemployment.

Although employability skills are categorized in many different ways: (1) Basic academic skills/ foundation skills (2) Personal management skills/personal qualities/personal attribute (3) team work skills. The most common sub skills under heading $1^{\text {st }}$ are: Good communication skills; (reading, writing, oral communication); scientific bent of mind; problem solving attitude; sound theoretical concepts, knowledge about current developments and willingness to learn new things and technologies. The common sub skills under heading $2^{\text {nd }}$ are: attitude and ethics; grooming and confidence; self management; self motivation; self confidence; self control; self directed; social skills; sincerity; commitment; motivation; enthusiasm; integrity; personality development skill; managerial skill (interpersonal; team spirit; leadership skills; stress); ability to work for long hour; ability to deal with pressure; ability to focus and concentrate; adaptability and flexibility; The common sub skills under heading $3^{\text {rd }}$ are: Organizational and administrative abilities etc.

However, the fresher EE professionals are lacking in most of these skills. Therefore, along with domain knowledge there is a need to develop employability skills. Some of the themes of training needs during professional studies for ensuring employment and developing employability skills are:

- Enhancing domain knowledge with correlation between theory and professional practices;

- Enhancing theoretical understanding with virtual learning/e-learning/simulation tools and using other ICT assisted technology;

- Conducting workshop on career counselling, planning and career mapping;

- Arrangement of personality development and skill development workshop (Enhancing communication skills through discussions and other interactive modes of communication; motivation \& leadership skills; ICT \& Computer skills);

- Arranging training facilities for competitive examination such as GATE/GRE/GMAT/TOEFL/PSUs/CAT;

- Strengthening industry-institute interaction and partnership activities. Moreover, identifying industrial problems from industries and other corporate sectors for live project work;

- Awareness about fellowship opportunities aboard;

- Global exposure and awareness about current trends in engineering and technology;

- Awareness about Indian engineering education system compared with the world;

- How to manage time and stress, to keep away from lifestyle disease and develop critical thinking;

The above training needs of EE professionals can be imparted by involving industry's inputs in the form of expert lectures/conducting short-term courses/taking up implant training/sponsored seminars/organizing workshops and future vision seminars/conducting visit to academic institutions and industrial R\&D sites/allowing students for industrial sourcing and sponsorship of student's projects and by continuing education for concept and skill updating. There is a need to impart and develop skills to each and every student and prepare the students to face the challenges that will boost up the employment opportunities.

\section{INITIATIVES AT BPS WOMEN UNIVERSITY}

\section{A. Continuing Professional Development Activities}

Continuing professional development activities are essentials and beneficial for continuous upgradation of knowledge and skills that become a necessity due to rapid advancements in technologies. The short-term courses are unique program aimed at imparting specialized hands on training in various thrust areas as per market demand and faculty specialization. A list of activities organized by Electronics and Communication Engineering department since its inception is summarized below:

1. Six weeks summer training programme entitled "Use of Computer Software (MATLAB, Orcad, 
Pspice, Xlinx) for Electronics Circuit Design and Testing", from $6^{\text {th }}$ June- $15^{\text {th }}$ July, 2011.

2. Organized several workshops on Free Open Source Software (FOSS) tools in coordination with Spoken Tutorial Project of NMICT IIT Bombay.

3. One week hands on training and workshop on "Engineering Problem Solving Using Matlab and SIMULINK", from $30^{\text {th }}$ September- $6^{\text {th }}$ October, 2013.

4. Two week UGC sponsored Workshop on "Embedded System Design and Simulation Tools", from $5^{\text {th }}-17^{\text {th }}$ February 2014 .

5. UGC sponsored workshop on "Computational Tool in Research", from $17^{\text {th }}-22^{\text {th }}$ February 2014.

6. Two week UGC sponsored FDP on "FOSS Tools in Higher Education from $24^{\text {th }}$ Feburary- $8^{\text {th }}$ March 2014.

7. ISTE-SRM sponsored Short Term Training Programme on "Hands on Experience in Signal Processing Using Matlab Simulink and Their Implementations" from $23^{\text {rd }}-29^{\text {th }}$ June 2014.

8. Three days workshop on "VLSI Design Using OrCad", from $29^{\text {th }}$ September- $1^{\text {st }}$ October 2014.

9. Two days National Conference on "Machine Intelligence and Research Advancement" from $19^{\text {th }}-20^{\text {th }}$ March 2015.

10. Three days workshop on "Hands on Training on LabView", from $1^{\text {st }}-3^{\text {rd }}$ April 2015.

The expected outcomes of these activities are stated in brief in the succeeding sub section.

\section{B. Expected Outcomes}

In general, a brief summary of the expected outcomes of the hands on application activities are as follows:

1. The hands on activities nourish skills and cultivate innovations for future.

2. Bridge the gap between the theoretical foundation and practical knowledge through engineering simulation.

3. Emphasis on usage of scientific computing package as a teaching tool and resource in engineering problem solving and instructional delivery across curricula.

4. Promotes student centered and computational project based learning thereby nurturing innovation talents among young professionals.

5. Accelerate innovation through model based design using graphical programming tool.

6. It provides a framework to enhance employability skills and employment of young technical professional

7. Prepare advance user community through education and training of future engineers.

In nutshell, such hands on activities strengthen technical and professional competency of students in diverse domain using industry standard scientific computing environment at various levels across technology integrated curricula, which will benefit their future study and profession certainly. It is essential and beneficial for continuous upgradation of knowledge and skills that become a necessity due to rapid advancements in technologies.

A snapshot of National Conference on "Machine Intelligence and Research Advancement" and UGC sponsored workshop on Computational Tools in Research is depicted in Fig. 1 and 2 respectively.

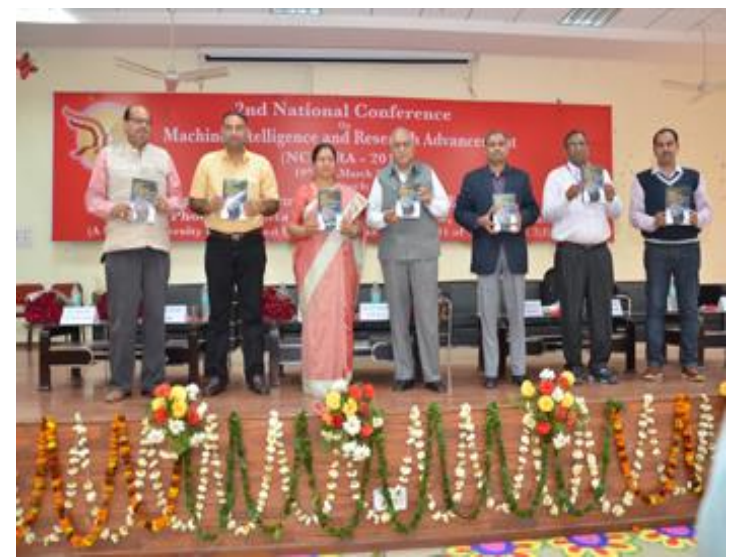

Fig.1. Snapshot of National Conference on "Machine Intelligence and Research Advancement"

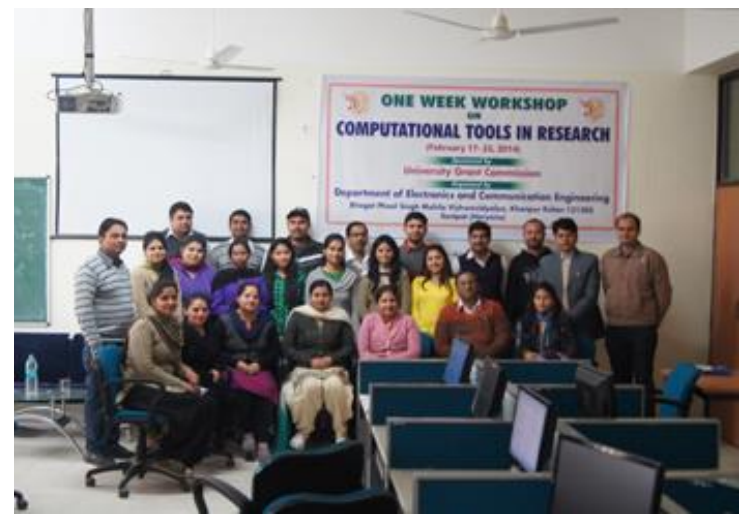

Fig.2. Photograph of workshop on Computational Tools in Research

\section{Student Centered Active Learning Using Teaching Method Aided by MATLAB/Simulink}

The author as an instructor is of the opinion that majority of instructors across the university teaching department in state employ traditional teaching learning approach. As a whole, the learning outcomes of the students are poor in mathematical intensive engineering courses. Thus, to improve the quality of engineering education and to foster deep learning approach, efforts have been made to integrate the same in instructional delivery.

Primarily foundation and core courses at BPSMV are being taught by integrating simulation tool during teaching learning process. The assimilation of active learning techniques and innovative tools such as ICT teaching aids, real life situation, mathematical application packages and free open source software play pivotal role 
in enhancing learning outcomes of students.

Active learning is a student centered approach. Adopting active learning techniques during course of teaching foundation courses and core courses such as problem/project based learning, collaborative learning, active listening, active writing, active reading, brainstorming, utilizing software tools and role playing enables students in thoroughly understanding and effectively mastering subject matter.

The assimilation of simulation tools in instructional delivery play vital role in understanding of basic theory, in analyzing complex system, in solving real world problems, in designing the projects, is raising the interest in technical profession, enabling flexible study and consequently motivating the students in learning [35-47]. Assimilation of general purpose scientific computing tool in teaching and learning activities are:

1. Modeling and simulation of electronics system using scientific computing environment.

2. Hands on training in Matlab, Simulink, its toolboxes and block sets.

3. Preparing advanced Matlab and Simulink users.

4. Matlab, Simulink and its application in basic, engineering science and foundation courses.

5. Pedagogy of modern teaching learning process using scientific computing environment.

In nutshell, such hands on activities nurture innovation for future.

\section{Encouraging Autonomous Learning Using FOSS}

Traditional laboratory courses are well integrated across electronics engineering curricula. However to promote autonomous learning using free open source software Scilab, Xcos should be encouraged to enhance students learning. The self learning model significantly reduces the amount of resource required, introduces flexibility in learning, and addresses the issues of shortage of faculty and infrastructure due to increase intake. The interested students may get training on open source software packages through Spoken Tutorial Project of Indian Institute of Technology, Bombay [4852].

In this section, the usage of Scilab is illustrated in self learning. As an example, one can investigate the response of $\mathrm{RC}$ electric circuit using the various built in function of Scilab.

The system function of the $\mathrm{RC}$ circuit is given as:

$$
G(s)=\frac{V_{c}(s)}{V(s)}=\frac{1}{\tau s+1}
$$

Laplace transform of unit step signal is

$$
L(u(t))=\frac{1}{s}
$$

Substituting the eq.(2) in (1), the Laplace transform of output signal is

$$
V_{c}(s)=\frac{1}{s(\tau s+1)}
$$

Applying inverse Laplace transform, the step response of the system is

$$
v_{c}(t)=\left(1-e^{-t / \tau}\right) \text { for } t \geq 0
$$

The step response of the system having step input with amplitude A i.e. $v(t)=A u(t)$ is given by

$$
v_{c}(t)=A\left(1-e^{-t / \tau}\right) \quad \text { for } t \geq 0
$$

The Scilab code to obtain time domain response of first order system using built in Scilab function is depicted in Fig. 3.

\section{Scilab Solution}

//examplestep1.sce

//Scilab code for analysis of first order system

clf()//Erase all plots on graphic window

$\mathrm{s}=\% \mathrm{~s} / /$ define $\mathrm{s}$ as a polynomial variable

$\mathrm{TF}=1 /\left(5^{*} \mathrm{~s}+1\right) / /$ define transfer function

$\mathrm{A}=$ syslin('c',TF); // define a linear system having parameters as $\mathrm{c}$ and $\mathrm{TF}$

$\mathrm{t}=[0: 0.1: 40]$; // define time index vector

response $1=\operatorname{csim}($ 'step',t, A)// simulate the response by specifying the three parameters as input, TF and time range

xbasc () ;

xsetech $([0.0,0.0,1.0,0.5])$

plot $2 \mathrm{~d}(\mathrm{t}$, response 1$)$

$\mathrm{xgrid}(2)$

xtitle("Step Response")

xsetech $([0.0,0.5,1.0,0.5])$

Fig.3. Scilab script for response analysis of RC circuit
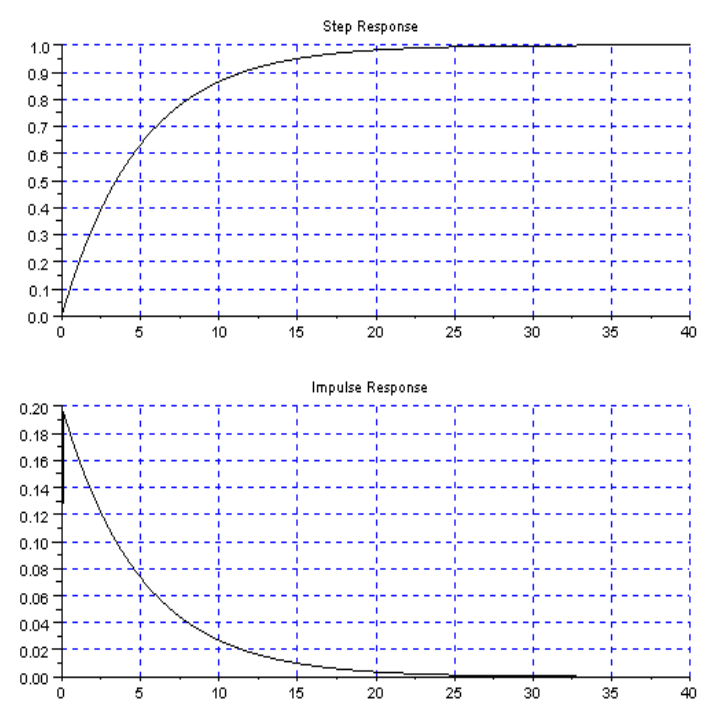

Fig.4. Step response of first order system using examplestep1.sce 
The execution of Scilab code 'examplestep1.sce' results the solution in the form of plot as presented in Fig. 4.

E. Cultivating Outstanding Application Oriented Engineering Professional through Laboratory Skill Development

The useful activities for cultivating outstanding application oriented engineering professionals are:

1. Skill development in Electronics and Communication laboratory experiments using GPSC.

2. Information and Communication Technology tool in engineering education.

3. Analyzing impact of scientific tool and hardware trainer laboratory experiments.

4. Handling electronics circuits and major course laboratory using FOSS.

In order to cultivate outstanding application oriented engineering professional the same is beneficial for skill development [53]. A snapshot of hands on training for professionals through laboratory skill development is as shown in Fig. 5.

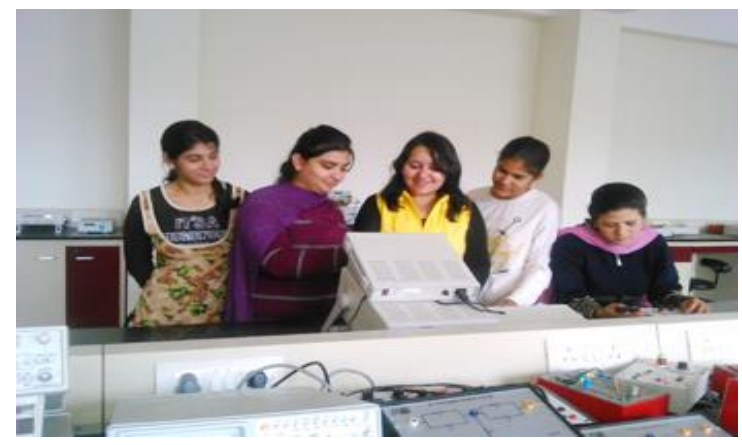

Fig.5. Snapshot of Students in Lab hands on training

\section{F. Emphasis on Oral and Written Communication Skills}

One of the effective way to improve written and oral communication skills is that during studies student should encourage to give presentation, discussions, writing technical and professional reports, writing different type of engineering documents, including design proposal, projects management plans, status reports, laboratory file and manual and other types of science writing. This framework along with language lab will equip the engineering professional with oral and written communication skills required for professional carrier and development. The following training activities and add on module strengthen oral and written communication skill.

1. Soft skills and motivational technique for personality development.

2. Communication skills and globalization in the current scenario.

3. Methodologies in teaching English to engineering students.
4. Communication and analysis skill development programme.

A snapshot of language lab for soft skill development is illustrated in Fig. 6.

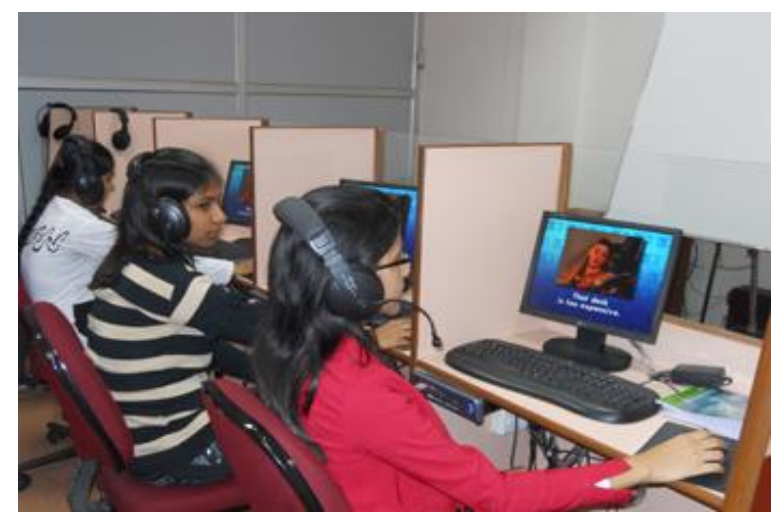

Fig.6. Snapshot of Language Resource Centre

To sum up, such activities bridge the gap on oral and written communication skills.

\section{G. Effective Assimilation of MATLAB Package}

Engineering simulation skills can be cultivated effectively by proper assimilation of general propose scientific computing package and dedicated simulation package across the curricula. Appropriate assimilation of general purpose scientific computing tool such as MATLAB/Simulink and add on for problem solving can be accomplished by vertical integration of same throughout the curriculum. In order to cultivate outstanding application oriented engineering professional the same is integrated horizontally and vertically across the curricula to design and develop a series of course curriculum experiments for students as depicted in Fig. 7.

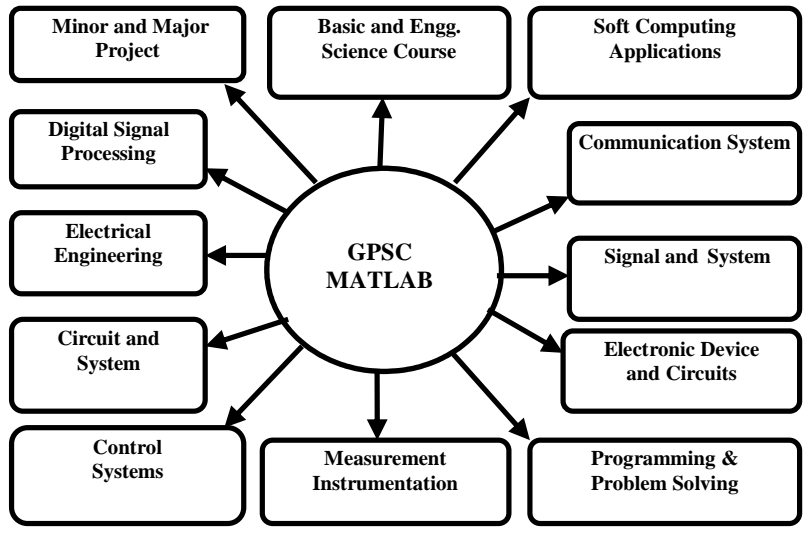

Fig.7. Schematic of Assimilation across the Courses in Curricula

Indeed, assimilation of industry standard general purpose scientific computing tool play a vital role in this direction.

\section{H. Integrating Virtual Labs}

In general, ICT aids and virtual simulation tools enhance teaching and learning across the domain. Virtual 
laboratory is effective solution for the institutions lacking in basic laboratory or no access to physicals labs or face teacher student's limitation. The student can be taught using internet; more efficiently with less expenses. It bridge the digital divide and geographical distances. The experiments can be accessed anytime anywhere, overcoming the constraint in time. Interactive simulations, animations and lab videos would be the highlights of these online labs. Individual practices can be promoted this way hence enabling better conceptual understanding of the experiments [54-56].

\section{Strengthening Students Curricular Activities}

In order to strengthen students curricular activities following actions needs to be initiated. A snap shot of activities in this direction is depicted in fig. 8 .

- More emphasize to practical exposure through workshop/industrial visit/project etc.

- Industry institute partnership for knowledge management.

- Student/faculty exchange nationally and internationally through MOU with the state university/R\&D institution and other institute of repute.

- Carrier counseling for Graduate Aptitude Test in Engineering (GATE)/GRE/TOFEL/MAT/CAT.

- Faculties should intensify their activities to attract highly qualified students. The seminar snapshot on personality development for students delivered by professionals is as shown in Fig. 8.

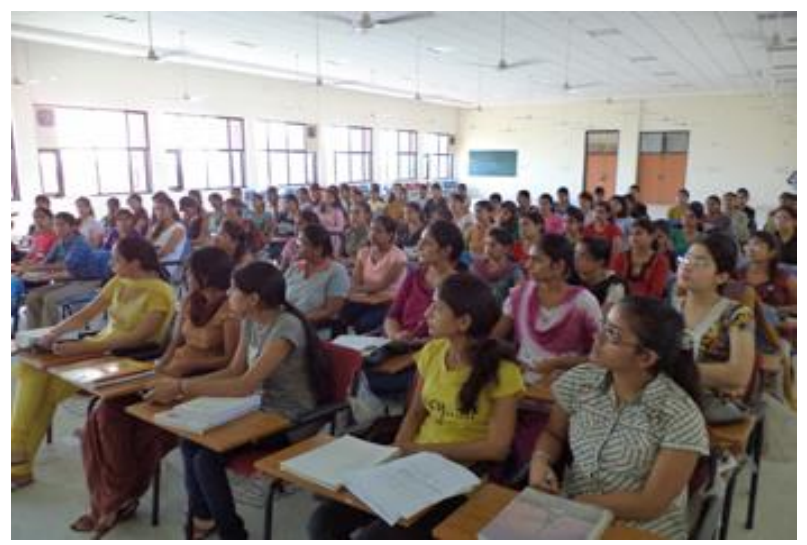

Fig.8. Snapshot of Seminar on Personality Development

\section{J. Ongoing Placement Activities}

To prepare highly skilled, self confident and motivated professionals, Department of Electronics And Communication Engineering conducted workshops, seminar, training etc. by specialized experts from academics as well as industrialists time to time. A tentative detail of ongoing placement activities in Department is depicted in Table 2.
Table 2. Pass out Students Scenario of Department of Electronics and Communication Engineering

\begin{tabular}{|c|c|c|c|c|c|}
\hline Batch & $\begin{array}{c}\text { Higher } \\
\text { Studie } \\
\text { s } \\
\text { M.Tec } \\
\text { h \& } \\
\text { MBA }\end{array}$ & $\begin{array}{c}\text { Gate } \\
\text { Qualifie } \\
\text { r }\end{array}$ & $\begin{array}{c}\text { Plac } \\
\text { eme } \\
\text { nt }\end{array}$ & $\begin{array}{c}\text { Defens } \\
\text { e } \\
\text { Servic } \\
\text { es }\end{array}$ & $\begin{array}{l}\text { Preparati } \\
\text { on for } \\
\text { Indian } \\
\text { Engineeri } \\
\text { ng Service }\end{array}$ \\
\hline $\begin{array}{c}2008- \\
12\end{array}$ & 15 & 2 & 11 & - & 12 \\
\hline $\begin{array}{c}2009- \\
13\end{array}$ & 23 & 1 & 08 & 1 & 10 \\
\hline $\begin{array}{c}2010- \\
14\end{array}$ & 20 & 6 & 10 & 1 & 14 \\
\hline
\end{tabular}

\section{CONCLUSIONS}

The domain of Electronics Engineering holds unprecedented opportunities and provides ample career prospects in diverse fields. It is a vital profession that opens avenues in multiple directions. Salaries and remuneration of EE professionals depend upon academic credentials and vary as per the nature of job. Sensing its huge potential, opportunities in this direction are limitless and the future of EE education seems to be very bright. Along with domain knowledge and technical expertise in order to ensure employment and employability through electronics engineering education, there is now an urgent need to reorient teaching and learning in the engineering institutions to meet the requirement of technocrats for contributing effectively in the $21^{\text {st }}$ century. In order to address this challenge, following recommendations are made to ensure employment and employability of young specialists:

- Employability skills should be introduced in nation's engineering academic curricula as add on module and made compulsory for all engineering students. Moreover, academic institutions have to focus on these important generic skills through innovative teaching methods, seminars, workshops, industrial and practical training, changing pedagogical style from teacher centric to student centric, activity based session, role plays and discussion etc. These skills should be imparted through outsourcing as per needs in a year. The apex regulatory bodies and higher education department should recommend the same through appropriate justification.

- Inter university and inter-departmental competitions among students on employability skills should be encouraged to stimulate interest in learning employability skills.

- Emphasizing on work integrated learning through industrial training after $2^{\text {nd }}$ and $3^{\text {rd }}$ year for 5 to 6 weeks. Moreover, keeping dedicated $7^{\text {th }} / 8^{\text {th }}$ semester for industrial training is also highly advantageous. 
- Skill building and practical training should be given equal importance to apply the class room learning in practical environment.

- Designing a model course curriculum and a National system of training for college and institution all over India. This model course should be treated as a bare minimum for academic institutions.

To sum up, EE professional employment and skill gap can be addressed only when academic institutions, industrial organizations and government work together hand in hand. The lack of awareness about career opportunities and non-inclusion of employability skills in engineering curricula seem to be the main gap in hindering placement in engineering education. Awareness about career opportunities and integrating employability skills into curricula will provide a new and effective means for revitalizing, enhancing and addressing the growing needs of placement in engineering institutes. It leads quick decision in the area of choice and to have a focus on the same thus ensuring employment. The present paper is an effort to find out means for ensuring employment and employability for engineering graduates and young technocrats in broader domains of ICT, electronics engineering, computer science engineering and other disciplines to prepare a workforce of highly skilled, self confident and motivated graduates in the $21^{\text {st }}$ century. Addressing the issues and challenges to impart quality education to ensure employment and employability is a matter of great concern.

\section{ACKNOWLEDGMENT}

The authors gratefully acknowledge the contribution of BPSMV University administration, UGC, ISTE-SRM for providing funds to organize hands on training, workshops, Faculty Development Programme etc. Further acknowledge the thanks to UGC for funding M.Tech (ICT) innovative programme in teaching and research programme. The authors also acknowledge the contribution of individual for providing valuable suggestion and expert guidance in preparation of this manuscript. One can refer to various website for career planning and mapping, eligibility conditions including minimum educational qualifications, age, physical standard and other instructions from time to time.

\section{REFERENCES}

[1] Vijay Nehra, Sandeep Dahiya, Kiran Nehra, "The Development of Engineering Education in Haryana," WSEAS Transactions on Advances in Engineering Education, vol. 7, no. 10, pp. 311-323, Oct 2010.

[2] All India council for technical education, http://www.aicte.ernet.in.

[3] Ministry of Human Resource Development, http://mhrd.gov.in/

[4] Admission Brochure for B.E/B.Tech 2015-16, Haryana State Technical Education Society, Panchkula, Haryana, India. http//www.hstes.org

[5] Admission Brochure 2015-16, Bhagat Phool Singh
Mahila Vishwavidyalaya Khanpur Kalan, Sonipat, India. http//www.bpswomenuniversity.ac.in

[6] B. S. Sonde, "Electronics Engineering Education in India for knowledge society," IETE Technical Review, vol. 22, no. 1, pp.5-13, Jan-Feb 2005.

[7] Vijay Nehra and Sandeep Dahiya, "Emerging Opportunities of Electronics Engineering Education in Haryana," Indian Journal of Technical Education, vol. 34, no. 3, pp 83-90, July-September, 2011.

[8] Rangan Banerjee, Vinayak P. Muley, "Engineering Education in India," Macmillan Publishers Ltd, 2008.

[9] Gautam Biswas, "Undergraduate curriculum and evaluation mechanism, Profile of Engineering Education in India: Status, Concerns and Recommendations," Narosa Publications, pp. 90-101, 2010.

[10] V Saravanan, "Sustainable employability skills for engineering professionals," The Indian Review of World Literature in English, vol. 5, no. 2, pp. 1-9, 2009.

[11] Master list of Central Public Sector Enterprises, http://www.bsepsu.com/list-cpse.asp\#

[12] S R Yadav, "Career in telecommunication," Employment News, vol. XXXIV, no. 38, New Delhi Dec 2009.

[13] Anoop Singh Meena, "Job opportunities in telecommunication sector," Employment News, vol. XXXVII, no. 38, pp. 2, New Delhi, 23-29 March 2013.

[14] Amar Singh Meena, "Job Opportunities in Telecom Sector," Employment News, vol. XXXVII, no. 51, New Delhi, 23-29 March 2013.

[15] TMIE2E Academy Career Centre based in Secunderabad, "Computer Networking: A promising Career," Employment News, vol. XXXVIII, no. 1, 6-12 April 2013.

[16] M.P. Thapliyal, "Career in Information Technology," Employment News, New Delhi 23-29 July 2005.

[17] Sudeshna Das, "Get Embedded Right Away," Electronics for You, vol. 41, no. 1, January 2009.

[18] Uma Bansal, "Embedded Systems Can India move from Implementing to Initiating Products?," Electronics for You, vol. 41, no. 4, April 2009.

[19] Sudeshna Das, "Design Your Career in Very Large Scale," Electronics for You, vol. 41, no. 5, May 2009.

[20] The Indian Navy, "Indian navy invites final year engineering students to join as short service commissioned officers under university entry scheme course commencing," Employment News, Jun. 2014, vol. XXXIV, no. 38, 22-28 June 2013.

[21] The Indian Air Force, "Invites enterprising and adventurous men to join the Indian air force as commissioned officers in flying technical and ground duty branch," Employment News, vol. XXXIV, no. 38, 8-14 June 2013.

[22] UGC, Universities, http://www.ugc.ac.in/page/UGCRegulations.aspx

[23] Nandini Jawli, Major Strides in Higher Education, Employment News, vol. XL, no. 21, 22-28 August 2015.

[24] CSIR/Careers and Opportunities, http://www.csir.res.in

[25] Information brochure for Training Schemes and Employment Description for One-year Orientation Course for Engineering Graduates and Science PostGraduates for the year 2011-2012, Two-year DAE Graduate Fellowship Scheme for Engineering Graduates and Physics Post-Graduates for the term beginning in 2011 http://www.oces.hbni.ac.in/information_brochure.php

[26] Union Public Service Commission, http://www.upsc.gov.in

[27] Union Public Service Commission, "Engineering Services Examination, 2013," Employment News, vol. XXXVIII, 
no. 1, 6-12 April 2013

[28] Sudeshna Das, "Robotics: Do you have it in you?," Electronics for You, vol. 41, no. 12, December 2009.

[29] Sudeshna Das, "Empower yourself with Power Electronics," Electronics for You, vol. 41, no. 3, March 2009.

[30] Sudeshna Das, "Mount Your Career Firmly in SMT," Electronics for You, vol. 41, no. 2, February 2009.

[31] GATE 2015, http://gate.iitk.ac.in/GATE2015/docs/ib.pdf

[32] Naipal Singh, "Career opportunities in human resource management," Employment News, New Delhi, 28 August - 3 September 2010.

[33] NASSCOM, http://www.nasscom.in/

[34] FICCI, http://www.ficci.com/

[35] Khadije Khatiri1, Fatemeh Rabiee, The Role of Simulation Software in Learning and Reminding (Case Study on MATLAB, Packet Trace, Pspice and Opnet), J. Basic. Appl. Sci. Res.,vol. 2, no.6, pp.6178-6181, 2012.

[36] The Math Works Inc., Natick, Massachusetts, MATLAB, 1993: http://www.mathworks.co.uk.

[37] Bober W and Stevens A, Numerical and Analytical Methods with Matlab for Electrical Engineers, CRC Press, 2013.

[38] Michal Blaho, Martin Foltin, Peter Fodrek and Jan Murgas, Education of Future Advanced Matlab Users, MATLAB-A Fundamental Tool for Scientific Computing and Engineering Applications-Volume 3, InTech, 2012.

[39] M. Blaho, M. Foltin, P. Fodrek and P.Poliacik, Preparing advanced Matlab users, WSEAS Transaction on Advances in Engineering Education, vol.7, no.7, pp.234-243, 2010.

[40] S. Jain, Modeling and simulation using Matlab-Simulink, Wiley India, 2011.

[41] Michal A. Gray, Introduction to the simulation of dynamics using Simulink, Chapman \& Hall/CRC, 2011.

[42] Vijay Nehra and Sandeep Dahiya, Effectiveness of MATLAB Simulation Tool in Circuit and System, In Proceedings of Emerging Trends in Electronics and Communication Technologies, NCETEC-2010, pp 169174, 24-25 December 2010.

[43] Tahir, H. H., Pareja, T. F., MATLAB package and science subjects for undergraduate studies. International Journal

for Cross-Disciplinary Subjects in Education, vol.1, no1, pp.38-42, 2010.

[44] Vijay Nehra, "Engineering Simulation Using Graphical Programming Tool Simulink: Putting Theory into Practice," in Proc. of TEQIP Sponsored National Conference on Contemporary Techniques and Technologies in Electronics Engineering, DCRUS\&T, Murthal, 2013, pp. 372-377.

[45] Vijay Nehra, "MATLAB/Simulink Based study of different approaches using mathematical model of differential equations," I.J. Intelligent Systems and Applications, vol.6, no.5, pp.1-24, 2014.

[46] Vijay Nehra and Ritu Sehgal, "Symbolic Computation of Mathematical Transforms and It's Applications: A MATLAB Computational Project Based Approach," IUP Journal of Electrical and Electronics Engineering, vol. 8, no. 1, pp.53-76, 2015.

[47] Sandeep Dahiya, "An Outline of Simulation Software Packages to Cultivate Outstanding Application Oriented Technocrats: Innovation for Future," in Proc. 2nd International conference on Computing for Sustainable Global Development, New Delhi, $11^{\text {th }}-13^{\text {th }}$ March, 2015, pp. 76-79.

[48] Vijay Nehra and Aruna Tyagi, "Free open source software in electronics engineering education: a survey,"
International Journal of Modern Education and Computer Science, vol. 6, no. 5, pp. 15-25, 2014.

[49] Spoken Tutorial on Scilab, Scilab, http://www spoken tutorial.org

[50] Hema Ramchandran and Achuthsankar S. Nair \&, SCILAB (A Free Software to MATLAB), S. Chand Publishing, 2012.

[51] Leros A. and Andreatos A., Using Xcos as a teaching tool in simulation course, In Proceedings of the 6th International Conference on Communications and Information Technology (CIT '12), March 7-9, 2012,121126, Recent Researches in Communications, Information Science and Education, World Scientific and Engineering Academy and Society (WSEAS) Stevens Point, Wisconsin, USA.

[52] Campbell, Stephen L., Chancelier, Jean-Philippe, Nikoukhah, Ramine, Modeling and Simulation in Scilab/Scicos with ScicosLab 4.4,Springer

[53] Vijay Nehra and Sandeep Dahiya, "Effectiveness of ICT to Enhance Problem Solving, Simulation, Experimental and Communication Skills: Experiences, Observation and Recommendation," in Proc. of the $7^{\text {th }}$ National Conference; INDIACom-2013,Computing For Nation Development, Bharati Vidyapeeth's Institute of Computer Applications and Management, New Delhi, $7^{\text {th }}-8^{\text {th }}$ March, 2013, pp.151-156.

[54] Heinz-Dietrich Wuttke, Karsten Henke, Nadine Ludwig, "Remote Labs versus Virtual Labs for Teaching Digital System Design", International Conference on Computer Systems and Technologies - CompSysTech' 2005, pp. IV.2-1 to IV.2-6.

[55] Nesimi Ertugrul, "Towards virtual laboratories: A survey of LabVIEW teaching/learning tools and futuretrends",wwwdiscoverlab.com/References/Ertugrul.p df

[56] Denise Consonni, Marcio F. Azevedo, Osvaldo Bernardo Neto, Ronaldo C. Rogeri, "Applications of virtual instruments in Electrical Engineering Education", International conference on engineering education and research "Progress through partnership, pp. 1075-1088, 2004 Ostrava.

\section{Author's Profiles}

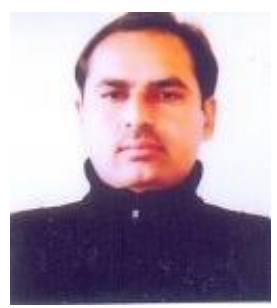

Sandeep Dahiya is presently working as Assistant Professor in Department of Electronics and Communication Engineering, Bhagat Phool Singh Mahila Vishwavidyalaya Khanpur-Kalan, Sonepat since July 2009. He also served as Lecturer in Hindu College of Engineering, Sonepat for 8 years. He is having 14 years of experience in academic frontiers. He received his B.E. in Electronics Engineering in 2000, M.Tech in Electronics and Communication Engineering in 2006 and currently pursuing $\mathrm{PhD}$ in Electronics \& Communication Engineering from UIET, MDU Rohtak. He has to his credit published 21 articles published and presented in refereed journals and proceedings. $\mathrm{He}$ has convened/coordinated 07 national workshops on design and simulation tools for students and faculty, UGC sponsored faculty development programme and national conference at University. He was also the Training and Placement Officer of Electronics and Communication Engineering Department and member of University Placement and Counseling Cell. He is 
also the recipient life member of Scientific and Professional societies such as Indian Society for Technical Education (ISTE), Computer Society of India (CSI) and Institution of Electronics and Telecommunication Engineers (IETE). His current area of interest includes Optical Interconnects in VLSI, Digital Circuit \& Systems and Simulation \& Modeling.

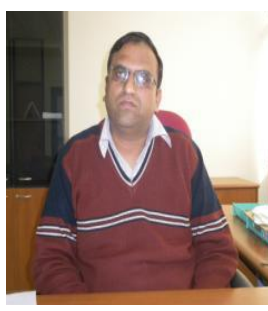

Vijay Nehra received his B.Tech degree in Electronics and Communication Engineering from JMIT, Radaur, Kurukshtra University, Kurukshetra in 2000 and M.E degree in Electronics from Punjab Engineering College, Chandigarh at Panjab University, Chandigarh in 2002. $\mathrm{He}$ earned Ph.D degree in Electronics and Communication Engineering in 2009 from Maharshi Dayanand University, Rohtak. He is currently working as professor in the Electronics and Communication Engineering Department at the Faculty of Engineering and Technology, Bhagat Phool Singh Mahila Vishwavidayala, Khanpur Kalan, Sonipat, Haryana, India.

Prof Nehra has held various senior positions in University administration and he has served as founder Dean, Faculty of Engineering and Technology and founder Chairperson, School of Engineering and Science from 2008 to 2011. In this position, he started UG, PG and Research programme in Electronics and Communication Engineering, Computer Science \& Engineering and Fashion Technology. He has been instrumental in setting up of School of Engineering and Science and designed syllabi, developed course curriculum and scheme of examination, UG \& PG ordinance, set up laboratory and library etc. He is actively involved in introducing design and simulation tools, programming and problem solving using general purpose scientific computing tool, open source software in teaching and learning at the BPS University. He has been member of various bodies viz University Court, Executive Council, Academic Council, Internal Quality Assurance Cell, Central Purchase
Committee, House Allotment Committee, Chairperson Undergraduate and Postgraduate Board of Studies, Chairperson Departmental Research Committee, member selection and screening committees etc.

$\mathrm{He}$ is presently Chairperson in the Electronics and Communication Engineering Department at the Faculty of Engineering and Technology; Chairperson, Basic and Applied Science Department, Faculty of Science; and Director, University Placement and Counseling Cell. Dr. Nehra has a professional experience of 13 years in teaching, research, curriculum planning, laboratory development, educational administration, planning, management and execution. As an engineering faculty member he served at several places the Technological Institute of Textile and Science, Bhiwani; Chaudhary Devi Lal Memorial Engineering College PanniwalaMota; Guru Jambhewsar University of Science and Technology, Hisar and presently BPS Mahila Vishwavidayala, Khanpur Kalan, Sonipat.

His current area of interest include engineering education teaching strategies that promote professionalism and career development, learning style and innovative laboratories that crosscut the curriculum. He always emphasizes on student centered active learning and always encourages students in autonomous learning using design and simulation tools for solving a variety of engineering problems. He has over 35 publications in refereed journals and proceedings. He has organized 10 national workshops on design and simulation tools for students and faculty of University, UGC sponsored refresher course on ICT and one national conference at University. He is a life member of various professional societies such as ISTE, CSI, IETE, Institution of Engineers, Plasma Science Society of India. He is also the coordinator of UGC funded M. Tech ICT innovative programme for teaching and research in interdisciplinary and emerging areas.

How to cite this paper: Sandeep Dahiya, Vijay Nehra,"Ensuring Employment and Employability through Electronics Engineering Education: A Case Study of BPS Women University ", IJMECS, vol.7, no.11, pp.35-52, 2015.DOI: 10.5815/ijmecs.2015.11.05 